\title{
VITAL POWER OF POSTPARTUM WOMEN DURING NURSING HOME CARE $^{1}$
}

\author{
Mariely Carmelina Bernardi, ${ }^{2}$ Telma Elisa Carraro ${ }^{3}$
}

\footnotetext{
${ }^{1}$ This article was originated from the dissertation Poder vital de puérperas no domicílio: a enfermeira utilizando o Modelo de Cuidado de Carraro, submitted to the Nursing Graduate Program of the Federal University of Santa Catarina, in 2011.

2 Ph.D. Student in Nursing. Specialist in Obstetrics. Fellow, Coordenação de Aperfeiçoamento de Pessoal de Nivel Superior, Programa de Apoio a Planos de Reestruturação e Expansão das Universidades Federais. Santa Catarina, Brasil. Email: marielybernardi@yahoo. com.br

${ }^{3}$ Ph.D. Nursing. Professor, Department of Nursing, Graduate Program in Nursing, Federal University of Santa Catarina. Santa Catarina, Brazil. Email: telmacarraro@ccs.ufsc.br
}

\begin{abstract}
This is a qualitative and convergent-care study, using the framework of the Carraro Care Model, with the aim to identify how the variables that can interfere in the vital power of postpartum women manifest during home care provided by a nurse. Data were collected between April and June of 2011, using the Carraro Care Model during home visits for four women experiencing immediate and late postpartum. In the course of the home visits, the manifestations of variables interfering in the vital power of these women were diverse, oscillating between neutrality, negativity and positivity when faced with the cared provided, oriented and discussed. By identifying these manifestations, it is believed that the nurse can plan, act and evaluate the care provided, thereby positively influencing the vital power of postpartum women.
\end{abstract}

DESCRIPTORS: Nursing. Postpartum period. Home visit.

\section{PODER VITAL DE PUÉRPERAS DURANTE O CUIDADO DE ENFERMAGEM NO DOMICÍLIO}

RESUMO: Pesquisa qualitativa, caracterizada como convergente-assistencial, com objetivo de identificar como se manifestam as variáveis que podem interferir no poder vital das puérperas durante os cuidados realizados pela enfermeira no domicílio, na perspectiva do Modelo de Cuidado de Carraro. A coleta de dados ocorreu de abril a junho de 2011, utilizando-se do Modelo de Cuidado de Carraro durante as visitas domiciliares para quatro mulheres que vivenciavam o puerpério imediato e tardio. No decorrer das visitas domiciliares, as manifestações das variáveis que interferem no poder vital do ser humano foram diversas, oscilando entre a neutralidade, a negatividade e a positividade frente aos cuidados realizados, orientados e discutidos. Com a identificação destas manifestações, acredita-se que a enfermeira possa planejar, atuar e avaliar o cuidado, influenciando positivamente no poder vital da puérpera.

DESCRITORES: Enfermagem. Período pós-parto. Visita domiciliar.

\section{PODER VITAL DE PUÉRPERAS DURANTE LOS CUIDADOS DE ENFERMERÍA EN DOMICILIO}

\begin{abstract}
RESUMEN: Estudio cualitativo, caracterizado como convergente-asistencial, con el objetivo de identificar como se manifiestan las variables que pueden interferir en el poder vital de las puérperas durante los cuidados realizados por la enfermera a domicilio, en la perspectiva del Modelo de Cuidado de Carraro. La recolección de datos ocurrió de abril a junio de 2011, utilizándose el Modelo de Cuidado de Carraro durante las visitas domiciliares a cuatro mujeres que experimentaron el puerperio inmediato y tardío. Durante las visitas domiciliarias, las manifestaciones de las variables que interfieren en el Poder Vital del ser humano fueron diversas, con oscilaciones entre la neutralidad, la negatividad y la positividad frente los cuidados realizados, orientados y discutidos. Con la identificación de estas manifestaciones, se acepta que la enfermera pueda planificar, actuar y evaluar el cuidado, influyendo positivamente en el poder vital de la puérpera.
\end{abstract}

DESCRIPTORES: Enfermería. Período de post-parto. Visita domiciliaria. 


\section{INTRODUCTION}

The postpartum period is a phase of both physical and emotional adaptation, when the woman experiences the dilemma between the expectations that were built during the pregnancy and the reality following childbirth. ${ }^{1}$ According to the Ministry of Health, the postpartum can be didactically divided into: immediate (from day 1 to day 10), late (day 11 to day 42 ) and remote (from day 43 on), ${ }^{2}$ and despite being a period of greater vulnerability compared with the other stages of pregnancy and childbirth, it is the period when women receive less care from the health care team. ${ }^{3}$

An existential transition occurs during the postpartum period due to some emotional aspects, including: the relationship between mother and baby is initially unstructured; depressive symptoms due to anxiety aroused by the arrival of the baby; the baby is no longer idealized, but a real and different being from the mother; the baby's needs are more prioritized than those of the mother, as well as protection and support, which are essential to the postpartum woman in this period. ${ }^{4}$

For this phase to be experienced in a satisfactory manner, it is believed that nursing is capable of mobilizing the environment into which the postpartum woman is inserted, providing her and her family with favorable conditions to their health and to strengthen her vital power, which is a life force innate to human beings, ${ }^{5}$ being an internal, intrinsic and latent energy which can be directed both towards life and death. ${ }^{6}$ Vital power is a force to be positively encouraged and directed to the specific transition that occurs during the postpartum period, both by the family and the nurse.

Two categories of variables were used in this study: the first is the subjective, including interpersonal relationships, planning the future, perceptions and coping with the moment, incentive/motivation, beliefs and values, emotional state, feelings and self-image. The second category is the objective, represented by nursing consultation, nutritional status, sleep and rest, external environment, risks and the health care team. ${ }^{5}$

One of the strategies for the nurse to recognize these variables may be the home visit (HV), which, in addition to being recommended by the Ministry of Health, is a strategy for reorganizing the health care system, capable of making it more humane and promoting its problem-solving potential. $^{7}$
Therefore, the aim of this study was to identify how the variables that can interfere in the vital power of postpartum women manifest during the home care provided by nurses, in the framework of the Carraro Care Model (CCM).

\section{THEORETICAL-METHODOLOGICAL FRAMEWORK}

This is a Convergent-Care Study (CCS) with the aim to find alternatives or minimize problems, and make changes and/or introduce innovations to the conjuncture of the practice in which the investigation takes place. Study participants need to actively engage and participate, so this is a type of study that combines theoretical knowledge and professional practice. ${ }^{8}$

This study used the CCM, which contributes to nursing practice for ordering procedures, as well as a dynamic and changing process that requires creativity. ${ }^{9}$ The CCM consists of five interrelated steps and, as indicated by the CCS, allows research to be performed simultaneously with the care, in this case, of postpartum women, in an effective and humane manner focused on increasing the potential of their vital power.

This model was chosen to facilitate reasoning regarding the concepts and their relationships, outline the process of nursing care, and represent the lived world expressed verbally through a diagram, offering the health care professional support necessary for the work that s/he intends to carry out. ${ }^{9}$ The adaptation of the CCM to the theme (Figure 1) served as the theoretical framework for this study, and enabled the interrelationship between the concepts of nursing, human being, environment, health care and vital power.

Data were collected between April and June of 2011, in Corbélia, state of Paraná, Brazil. This municipality was chosen due to the professional experience and familiarity of the researcher-caregiver with the place, and her interest in conducting a specific study to identify needs and opportunities for improving nursing care in the area of women's health.

The study participants were four postpartum women who received a visit from the researchercaregiver in the hospital, when they were invited to participate. During the clarification of the study, the proposal was to perform two HVs, in the immediate and late postpartum period, using the adapted version of the CCM to the theme, capable of providing support for data collection through 
nursing care, a semistructured interview and participant observation. Analysis was performed through the fifth stage of the CCM, named "Moni- toring and appraising the trajectory," whereas interpretation was developed in three fundamental processes: synthesis, theorizing and transference.

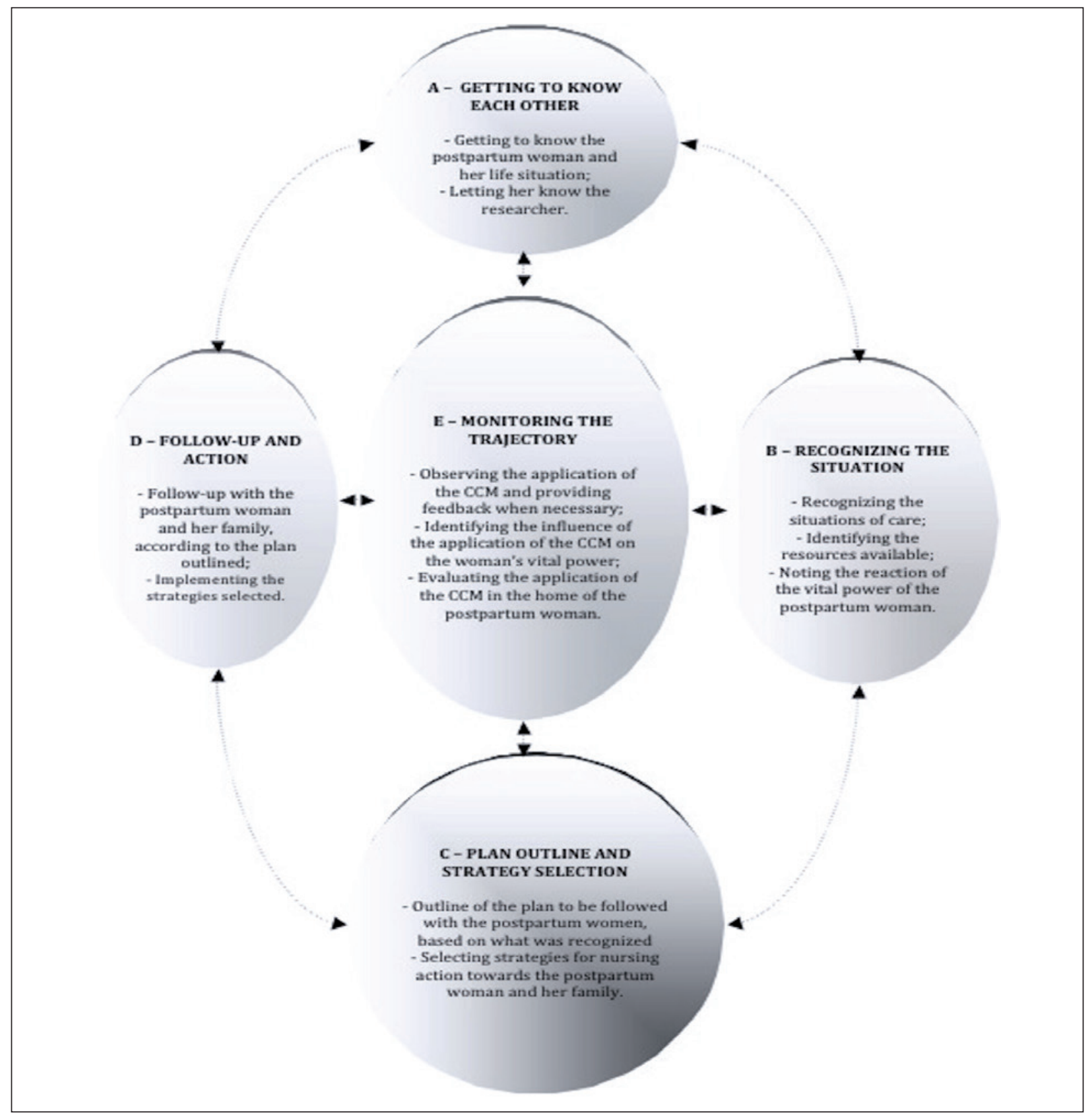

Figure 1 - Diagram of the Carraro Care Model adapted to the theme - Vital power of postpartum women at home: a nurse's use of the Carraro Care Model

This study complied with the recommendations of the Resolution 196/96 of the National Health Council, ${ }^{10}$ and was submitted to the Human Research Ethics Committee of the Federal University of Santa Catarina, being approved under protocol number 1823 in early 2011. After being informed regarding the study, the four participants, who were all aged older than 18 , signed a Free and Informed Consent Form. To ensure anonymity and preserve the identity of the participants, their names were replaced with the letter $\mathrm{P}$, representing the word postpartum, and sequential numbers. 


\section{RESULTS AND DISCUSSION}

Four postpartum women participated in this study: P1, 24 years, who lived with her husband, three children, mother and stepfather; $\mathrm{P} 2,34$ years, single, four children, spent postpartum period in her mother's house, and would then return to live with her eldest daughter; P3, 27, lived with her husband and two sons; and P4, 34, lived with her husband, three children and her parents.

A distinct follow-up was performed for each postpartum participant in relation to the time of the first $\mathrm{HV}$ and number of follow-up visits. The decision-making process of each follow-up visit was based on the needs perceived by the reaction of the vital power of the postpartum women, questions and/or problems resolved or forwarded to other health care professionals, as well as on achieving the study objective. Thus, in addition to one HV during immediate, and another in the late postpartum period, P1 received two HVs during pregnancy, and two visits were held in the hospital while she was in labor; $\mathrm{P} 3$ and $\mathrm{P} 4$ received an additional HV during the late postpartum, and one meeting was held with P3 in the central Primary Health Center (PHC) during the immediate postpartum period.

During the study, the involvement of primary and secondary health care professionals with the researcher-caregiver was strengthened, and as visits occurred with the postpartum women, and needs that needed action from different professional areas emerged, the care became more effective, fulfilling the proposal of the CCS. The variables that influenced the vital power of the postpartum women are described as it follows, as well as the manifestations during the care provided by the researcher-caregiver.

\section{Subjective variables interfering in the vital power of the postpartum women}

Because this is a potentially vulnerable period, the postpartum woman needs support from interpersonal relationships. Three study participants were able to rely on their mothers, the main source of care identified, which positively intervened in the vital power of these women: $I^{\prime} m$ calmer and relieved because I have my mother here with me, and she helps with everything, she takes care of me and the children (P1); I'm well, my mother helps me, she does everything for me (P2); my mother helps me bathe her [baby], because I am in pain (P4).

In these cases, it was noted that the presence and support of the mother during this period pro- vided tranquility, security, relief, help, care and comfort. This finding agrees with that of another study, which revealed mothers of postpartum women to be significant sources of knowledge, experience, financial assistance, help with the housework and hygiene care of the baby. ${ }^{11}$

Nevertheless, one participant's expectations were not met during the immediate postpartum period, and this had a negative effect on her vital power: when I was pregnant, I had other plans, I wanted to go to my mom's house, you know [...]. The worst phase passed [...]. My mom was supposed to come, but she had a big fight with my husband, and that's why she has not come here yet (P3).

In addition to the support from the mother, relationships with family, neighbors and partners also influenced directly the vital power of the postpartum women: my sister comes to bathe her [...]. The neighbor offered to help [...]. Fortunately he [husband] helps me when he can (P3).

Having a helping and supportive partner was what P2 wanted, but this was not the case, so that when mentioning the child's father, she appeared to be sad and undecided as to her future plans: I've already made a lot of plans in life, and now I'm calmer, I think it's not going to work out with him because he's younger, you know [...]. He went to see his daughter once in the hospital, and came here once with his sister. That's it (P2).

To qualitatively modify the meaning of fatherhood, it is necessary to value a more involved paternal model, in affective intensity and solidarity, ${ }^{11}$ as this is a process in constant construction, which occurs through interactions. ${ }^{12}$ In the case of P2, although her mother was taking care of her, she felt fragile and incomplete due to the lack of care and support from the father of her child, which interfered negatively in her vital power. This circumstance led to manifestations of searching for courage to face the moment more calmly, which also characterizes the variable perceptions and coping with the lived moment, and which is identified in a statement by $\mathrm{P} 2$ at a different time: I hope to have a quick recovery like the other times, but now I want to see if I can enjoy this daughter more, I want to take advantage more; the others I couldn't enjoy much when they were very little. And this is the last one. Based on a prior reflection, this statement made the postpartum woman perceive reality, face it and make plans for the future.

In the case of P3, by not having the support of her mother at this time, and understanding the needs of care for her son and herself, she devel- 
oped skills which she had not had in the previous postpartum period. [...] but after everything that happened, you can see that God gives us tools [...]. My sister was coming here every morning to bathe her. I was afraid, and like I told you, where I lived before it was my neighbor who bathed the other baby. This time I had to deal myself, my sister couldn't help me more [...] (P3).

During the postpartum period, the baby's bath and dressing the umbilical cord stump are procedures that require skills from more experienced people, so often grandmothers perform this task, and when these are not present, aunts and neighbors assume this care. ${ }^{11}$

Being a period of adjustment to new routines, the postpartum period requires both physical and emotional support, in order to be faced in a peaceful and healthy manner, as part of the process of human development. ${ }^{1}$ In this sense, the nursing professional can provide care through strategies which also provide incentive/motivation to the postpartum mother.

All of the participants reacted with surprise to the proposal to visit the mother at home during the postpartum period, as if it was a form of care that did not fit the reality of the participants. One of the statements stood out at the time of the invitation to participate in the study: oh good, where I live is so far away, it's so hard to leave, even more so without a car, the health center is so far [...]. But will you really come? It's in the country! (P3).

According to the Brazilian Ministry of Health, one home visit is recommended within the first week after the baby's birth, and if this is classified as at-risk, the visit should occur within the first three days after discharge. ${ }^{4}$ In this perspective, it is necessary to collectively reflect on the HV, face the difficulties inherent to this strategy, and to reaffirm and develop the cumulative potential, using as reference the specific context, peculiarities and interpretations of the individuals involved..$^{13}$ Because it is a period filled with weaknesses and risks for new mothers, it is noted that the care offered by the HV was a factor that increased the potential of vital power.

Another form of incentive/motivation for care was a kit with items for caring for the newborn, offered by the county, and received by P3 in the PHC in the following manner: oh, how beautiful, it has alcohol to clean the umbilical cord stump, gauze, how nice. I wasn't cleaning it because I didn't have alcohol (P3). This demonstrates the importance of knowing the context in which the postpartum mother is inserted to identify the risk factors related to the care given during this period.
Appreciation of the care provided by the postpartum mother to her newborn baby, through praise from the researcher-caregiver, also made the women demonstrate happiness and ability to care effectively, which positively influenced their vital power. Thus, it is possible to state that "the more a mother feels emotionally and materially supported by the social environment, the more she is able to organize the child's activity and provide rules and stimuli according to individual need and age." 14:743

Learning to value beliefs and values is vital for nurses, and can positively influence the vital power of mothers. For this purpose, one needs to act comprehensively and know how to listen carefully, because the women's fears of being judged by their attitudes reign over the care provided.

During the second HV to P4 and P2, the following accounts were highlighted: look, I didn't believe it, but it really works, with milk, fennel, ginger and sugar. I took it in the morning, and in the evening I was already feeling different. I felt the breast was hurting more, and when I squeezed the nozzle [nipple] it already had milk (P4); wow, if you saw how it was before, if not for the chicken fat I don't know what would become of me, it's what [chicken fat] healed all that bruising (P2).

Although they were performing these practices, P4 had diversified her diet and increased hydration, while P2 was sunbathing, hydrating her nipples and areola with her own milk, and taking care that her baby properly latched on, according to the guidance provided during the first $\mathrm{HV}$, care that may have aided these processes. Although there are studies on beliefs and values, none is related specifically to the use of chicken fat for healing cracks on the nipple, or the tea cited above. Yet, it is necessary to understand that this knowledge is not superior nor inferior to that proven scientifically, since it is based on positive experiences, and only reveals different ways of facing reality, allowing the nurse to find the symbolic dimension of care and to plan it congruently, through incentives, negotiation or restructuring of the care provided, always seeking the well-being of the postpartum mother and newborn. ${ }^{15}$

The emotional state and feelings experienced during the postpartum period are also key variables to be observed by the nurse, as based on them it is possible to assess how the new mother is doing, and how best to intervene. For instance, P2 showed herself to be satisfied and secure when she reported on the care and support offered by her mother, yet disappointed at the lack of help 
and support from her daughter's father. All of the women demonstrated and/or reported insecurity in caring for the umbilical cord stump, doubts regarding breastfeeding and care of the breasts, in addition to fear about risks related to the postpartum phase. Therefore, with a view towards strengthening the autonomy of the postpartum mother in face of the changes and novelties in this new phase of life, it is essential that nurses provide support and bonding by listening to anxieties. ${ }^{16}$

Regarding self-image, it is difficult for the postpartum women to show how they perceive themselves in this period. Only P1 stated: I think I'm beautiful, without the hideous belly [during pregnancy]. I feel like Gisele Bündchen. Before I felt like a goose (P1).

For this woman, pregnancy was considered a burden, something uncomfortable that gave her unsatisfactory body shapes, whereas the postpartum period is seen as a phase of renewal and recovery of beauty. In this sense, the perception of one's own body in this period relates to how each woman sees and reacts to the changes that occur in the face of subjectivity, relationships and her culture. ${ }^{17}$

Thus, the subjective variables here presented and discussed, which interfere in the vital power of postpartum women, are interrelated and determine the need and importance of nurses to be sensitive and understand the context of each individual and, based on this, undertake home care in order to exercise their skills and enhance the vital power of women experiencing this period full of changes.

\section{Objective variables interfering in the vital power of the postpartum women}

As a means of supporting care practice decisions, it is essential to recognize the situations of care, the resources available and the reaction of the vital power. Therefore, the interaction established in the nursing consultations during the HVs was an effective means of caring for the postpartum women, and this study positively influenced their vital power: It's good when you come, I feel better, and it's better than having to go to the health clinic [...]. I can't even think of leaving home, it's difficult, I have small children, we don't have a car, the health clinic is too far to walk to, especially after having a cesarean (P1).

Nurses can play a key role through planning, performing and evaluating the care, and at the same time have a positive influence on the vital power of postpartum women, so that she faces tough times in the best way possible, recognizing that she is capable. Event that was recognized and valued by P3: wow, you have no idea how much you helped me. I learned a lot that I didn't know [...]. As my sister didn't come anymore, I remembered the tips you gave me and found the courage to bathe her [baby] [...]. But now I'm used to taking care of her properly, not to mention that I'm eating better, feeling stronger, taking better care of myself (P3). Thus, the care provided at home is intended to provide actions that are more integrated to the individual and her family, and foster integration between the different health care services. $^{7}$

With regard to nutrition, it was noted that although orientation was provided on the need for different types of nutrients in this period, most of the postpartum women preferred to follow the directions from the family culture, which is important to be respected by nurses, as long as there is no perceived damage to health, both to the mother and the newborn.

P2 had an appointment scheduled with a nutritionist. As much as the researcher-caregiver had stressed the importance of nutritional monitoring, she did not attend the appointment, explaining that she was following a diet recommended by her mother, based on soup, crackers and teas, but that she was already modifying it due to the directions given during the home visits, and her own perceptions regarding the need for a more diversified diet. According to P3: this time, I ate everything I wanted during pregnancy. Because, in her first experience with postpartum: I ate pork again and ruined my cesarean. Honestly, I ate it to see if it was myth or fact, so I verified that it really does cause harm [...]. Additionally, she said: if I eat bell pepper, it makes the baby's skin ugly, and who will want a daughter with a problem? (P3).

All of the postpartum women reported on nutritional care, and consumption of soups and teas predominated in the results. In this sense, certain foods are avoided because the women perceive them as inappropriate for this period, mainly because they can infect the stitches and pass into breast milk, causing colic for the baby. ${ }^{3}$ Thus, there is a conflict in this period in regard to this variable, because when the woman is deprived of a food she likes it negatively affects her vital power, whereas avoiding something because she believes that it will benefit her child and enhance her restorative process strengthens this inner force.

In regard to the sleep and rest variable, $\mathrm{P} 4$ states: she [baby] likes to nurse a lot, at night too, it's 
tiring, you know? But then, in the morning when she sleeps more, I sleep too (P4).

In this context, the importance is emphasized of the postpartum mother to discern and define how much is needed to organize to face this period so that it does not overload her. Nurses can collaborate to provide care to a "singular, comprehensive, indivisible, irreplaceable being, complete in her conception of interacting with the world." 5:28

The external environment of each postpartum had its peculiarities, offering both negative and positive influences on her vital power. While P1 remained in the hospital, she said: if I was at home, I wouldn't have gotten this headache because there I have my mother to help [ ... ]. I can't wait to go home, so I can feed myself better (P1).

The homes were clean and ventilated, providing for adequate recovery of the women. By mobilizing the environments into which postpartum women are inserted, nurses can provide them and their families with favorable conditions to health, and increase the potential of their vital power. ${ }^{5}$ After all, care involves promoting and maintaining the health of woman and child, and also promotes an environment that helps and supports the family. Thus, the care recommended should be individualized, and danger signs should be recognized in order to take appropriate measures. ${ }^{18}$

The main risks identified in the postpartum study participants were infection, breast engorgement, and impaired skin integrity. Given these factors, the researcher-caregiver used an individualized and reflective approach, together with the postpartum mother and her family, to search for alternatives that minimized these risks and positively influenced her vital power.

Breastfeeding is a primary concern for new mothers, being a complex practice that requires different sorts of care. Postpartum women are often incorrectly oriented by health professionals. During the second $\mathrm{HV}$ to $\mathrm{P} 2$, she indicated that she had gone to the PHC to vaccinate her daughter, and took the opportunity to speak with the nurse about the pain she felt from breast engorgement, which was also hindering breastfeeding. The postpartum woman said that the professional: [...] looked at it and told me to go home to do a warm compress, and asked if I had a breast pump (P2). These practices were not performed by the mother because of the directions performed by the researcher-caregiver in the first HV. P2 reported that there was a considerable decrease in the amount of milk the day after she became stressed.

In this context, the care of the postpartum woman by the health care team needs to be reevaluated, discussed and reorganized, given the need and importance of interdisciplinary care. After all, nursing care provides a moment of interaction between those who care and who is cared for, and aims to awaken and/ or strengthen the vital energy responsible for the restorative process. ${ }^{19}$

Also regarding the health care team, P1 stated that one professional who dressed the surgical incision of the cesarean section in her home, after several days of monitoring, provided the material so that she could perform the procedure on her own. When asked by the researcher-caregiver about her care of the incision, it was found that P1 was using $70 \%$ alcohol for cleaning, provided by the health center in an oil can, to clean her daughter's umbilical cord stump. Because the health care professional had used a similar bottle, the postpartum mother thought that she was using the same solution. In this case, signs of infection were identified at three stitches on the incision, and it was necessary to clarify P1's doubts, and contact the nurse responsible for the unit, to refer her for medical evaluation. This referral strengthened P1's vital power. Thus, articulation between health care professionals contributed to comprehensive care, and facilitated the identification of health care needs for this period. ${ }^{20}$

Thus, the objective variables that affect the vital power of postpartum women generated important information to be considered by the nurses. The external environment, represented by the household in this study, is a means to be constantly transformed in order to benefit the postpartum mother in relation to sleep, rest and minimization of risks. By performing nursing consultation during the $\mathrm{HV}$, based on the adapted CCM to the theme, the possibility was identified of also influencing the postpartum mother's nutrition, as well as the relationship with the health care team and others involved, which consequently strengthened the study participant's vital power.

Given the subjective and objective variables presented, it was observed that changes in care occurred not only because the subjects were monitored and guided, but due to understanding and feeling the need to change by the participants themselves, to change some aspects of care that were impregnated in the family culture. 


\section{FINAL CONSIDERATIONS}

The subjective and objective variables that affect the postpartum participants' vital power manifest in different ways during the care performed, directed and discussed during the home visits, oscillating between neutrality, positivity and negativity. Thus, in order for the vital power of postpartum women to be positively encouraged, several actions can be taken by the nurse during the course of home care.

The application of the Carraro Care Model adapted to the theme via the Convergent Care Study, supported the nurse to undertake home care during the postpartum period in a comprehensive manner, which was viewed positively by the study participants.

Considering that the postpartum is a period that merits attention, the results of this study point to the need for the nurse to respect the new mothers in this period, observing how the objective and subjective variables presented here interfere in their vital power. Using these variables, the nurse may be able to plan, perform and evaluate the care, always with the purpose of positively influencing the vital power of the postpartum mother, thus promoting "care while thinking" and "thinking while caring."

Due to its complexity, vital power is a theme that encourages reflection, and sensitivity of nurses in order to be perceived, wisdom to be understood, and knowledge to be worked through the established interactions. Thus, it becomes a challenge, an instigating object of study, and requires new research in order to be better understood, perceived and strengthened in the care of human beings.

Finally, this manuscript ends with the following reflection and inquiry made by one of the postpartum women: [...] wow, it would be so good if at least in the first few days we always received care like this. The other times I gave birth I didn't have this, and it was hard. Good thing I had my mother, but what about those who don't? (P2).

\section{REFERENCES}

1. Penna LHG, Carinhanha JI, Rodrigues RF. A mulher no pós-parto domiciliar: uma investigação sobre essa vivência. Esc Anna Nery Rev Enferm. 2006 Dez. 10(3):448-55.

2. Ministério da Saúde (BR). Secretaria de Políticas de Saúde, Área Técnica de Saúde da Mulher. Parto, aborto e puerpério: assistência humanizada à mulher. Brasília (DF): MS; 2001.

3. Stefanello J, Nakano AMS, Gomes FA. Crenças e tabus relacionados ao cuidado no pós-parto: o significado para um grupo de mulheres. Acta Paul Enferm. 2008; 21(2):275-81.

4. Ministério da Saúde (BR). Secretaria de Atenção à Saúde, Departamento de Ações Programáticas Estratégicas, Área Técnica de Saúde da Mulher. Manual técnico pré-natal e puerpério: atenção qualificada e humanizada. Brasília (DF): MS; 2006.

5. Carraro TE. Resgatando Florence Nightingale: uma trajetória da enfermagem junto ao ser humano e sua família na prevenção de infecções [dissertação]. Florianópolis (SC): Universidade Federal de Santa Catarina. Programa de Pós-Graduação em Enfermagem; 1994.

6. Kunzler IM. O cuidado às mulheres no purpério de alto risco: aplicando o Modelo de Cuidado de Carraro, fundamentado em Florence Nightingale [dissertação]. Florianópolis (SC): Universidade Federal de Santa Catarina. Programa de PósGraduação em Enfermagem; 2006.

7. Kerber NPC, Kirchhof ALC, Cezar-Vaz MR. Considerações sobre a atenção domiciliária e suas aproximações com o mundo do trabalho na saúde. Cad Saúde Pública. 2008 Mar; 24(3):485-93.

8. Trentini M, Paim L. Pesquisa convergenteassistencial: um desenho que une o fazer e o pensar na prática assistencial em saúde-enfermagem. $2^{\mathrm{a}} \mathrm{ed}$. Florianópolis (SC): UFSC; 2004.

9. Carraro TE. Enfermagem: de sua essência aos modelos de assistência. In: Carraro TE, Westphalen MEA. Metodologia para a assistência de enfermagem: teorizações, modelos e subsídios para a prática. Goiânia (GO): AB; 2001. p.147-57.

10. Ministério da Saúde (BR). Conselho Nacional de Saúde, Comissão Nacional de Ética em Pesquisa. Resolução n. 196 de 10 de outubro de 1996: diretrizes e normas regulamentadoras de pesquisa envolvendo seres humanos. Brasília (DF): MS; 1996.

11. Martins CA, Siqueira KM, Tyrrell MAR, Barbosa MA, Carvalho SMS, Santos LV. Dinâmica familiar em situação de nascimento e puerpério. Rev Eletr Enferm [online]. 2008 [acesso 2011 Ago 07]; 10(4). Disponível em: http://www.fen.ufg.br/revista/ v10/n4/v10n4a13.htm

12. Meincke SMK, Carraro TE. Vivência da paternidade na adolescência: sentimentos expressos pela família do pai adolescente. Texto Contexto Enferm. 2009 Jan-Mar; 18(1):83-91.

13. Mandú ENT, Gaíva MAM, Silva MA, Silva AMN. Visita domiciliária sob o olhar de usuários do programa saúde da família. Texto Contexto Enferm. 2008 Jan-Mar; 17(1):131-40.

14. Fonseca VRJRM, Silva GA, Otta E. Relação entre depressão pós-parto e disponibilidade emocional materna. Cad Saúde Pública. 2010 Abr; 26(4):738-46. 
15. Kalinowski LC, Lenardt MH, Mazza VA, Lacerda MR, Wall ML. Beliefs and popular practice during postpartum period: integrated review of nursing productions. Online Braz J Nurs [online]. 2010 [acesso 2011 Ago 07]; 9(3). Disponível em: http:// www.objnursing.uff.br/index.php/nursing/ article/view/j.16764285.2010.3140/html

16. Vieira F, Coelho ASF, Cordeiro ACA, Bachion MM, Salge AKM. Utilização da taxonomia II da NANDA para avaliação da ansiedade puerperal na comunidade. Rev Gaúcha Enferm. 2010 Set; 31(3):544-51.

17. Salim NR, Araújo NM, Gualda DMR. Corpo e sexualidade: a experiência de um grupo de puérperas. Rev Latino-Am Enfermagem. 2010 Jul-
Ago; 18(4):732-9.

18. World Health Organization. Department of Making Pregnancy Safer. WHO Technical consultation on postpartum and postpartum care. Geneva (SW): WHO; 2010.

19. Sebold LF. Acadêmicos de enfermagem: o cuidar de si para promoção da saúde e evitabilidade do sobrepeso [dissertação]. Florianópolis (SC): Universidade Federal de Santa Catarina. Programa de Pós-Graduação em Enfermagem; 2008.

20. Trevisan ML, Lewgoy AMB. Atuação interdisciplinar em grupo de puérperas: percepção das mulheres e seus familiares. Rev Textos Contextos. 2009 Jul-Dez; 8(2):255-73. 